\title{
Consequence of Sujala Watershed Project on Accessibility to Rural Livelihood in Tumkur District of Karnataka, India
}

\author{
S. M. Mahalakshmi*, V. Govinda Gowda and M. N. Thimme Gowda \\ ${ }^{1}$ Department of Agricultural Extension, UAS, GKVK, Bengaluru-560065, Karnataka, India \\ ${ }^{2}$ Department of Agricultural Extension, ICAR-KVK, Konehalli, Karnataka, India \\ ${ }^{3}$ Department of Dry Land Agriculture Project, UAS, GKVK, Bangalore-560065, India \\ *Corresponding author
}

\section{A B S T R A C T}

\begin{tabular}{|l|}
\hline K e y w o r d s \\
Consequence, \\
Accessibility, \\
Livelihood, Sujala \\
and income \\
generating activity
\end{tabular}

\section{Introduction}

Watershed development is not an end in itself, but it is a means to an end, that of reducing the incidence of rural poverty (Turton, 2000). Watershed development programme activities by influencing rural livelihoods tend to attain the objective of poverty reduction. Project activities can influence rural livelihoods only when the livelihood changes brought by the watershed activities are sustainable. A livelihood is sustainable when it can cope with and recover from stresses and shocks and maintain or enhance its capabilities and assets both now and in the future, while not undermining the natural resource base" 
(Carney, 1998). Three key issues that sustainable livelihood highlights include: i) Well-being is not only about increased incomes. Other dimensions of poverty that must be addressed include food insecurity, social inferiority, exclusion, lack of physical assets, and vulnerability, ii) Household poverty is determined by many factors, particularly access to assets and the influence of policies and institutions, iii) Livelihood priorities vary and outsiders cannot assume knowledge of the objectives of a given household or group. The Sustainable Livelihoods (SL) approach to development and poverty reduction tries to take all these concerns into account. It aims to promote development that is sustainable not just ecologically, but also institutionally, socially and economically and to produce genuinely positive livelihood outcomes (rather than concerning themselves with narrow project outcomes, with resources or with output) (Ashley and Carney, 1999). The sustainable livelihoods framework presents the factors that affect the sources of people's livelihoods and also depicts the relationships between them. In a number of cases participatory methods have been used to identify the factors affecting sustainable rural livelihoods.

\section{Watershed approach in Karnataka}

The state depends on dry land for more than half of its food production. Therefore, more emphasis is given for dry land farming in the state by way of developing dry land areas on watershed basis. All India Soil and Land Use Survey in its revised atlas in 1990 has identified 35 important river basins and 3237 Watersheds in the country. In Karnataka 5 Rivers basins 218 Watersheds have been identified for development. The initial impetus, a World Bank initiated watershed development in Karnataka came from Kabbalnala Watershed in Kanakapura taluka of Bangalore rural District in the year 1984-
85. Later, four Dry Land Development Boards were set up, one in each Revenue division to implement watershed programmes in all the 19 districts in the State. It started in small way and picked up momentum during the 1985-86. The government of Karnataka initiated 175 micro model watersheds in each block around rain gauges spread over varied agro-climatic regions of the state. Followed by this, number of watershed development projects initiated by the NGOs with financial assistance from the external agencies along with development departments. Karnataka State has a strong history in managing watershed development programme effectively, which has given high priority for development of dryland areas. The watershed development is unique in terms of its comprehensiveness, unified approach, better co-ordination built in research linkage and allocation of sufficient budget. The State was considered as a model state in Watershed Development Programme and many other States followed Karnataka state watershed model. Following the good response to the programme, Department for International Development (DFID) had taken initiative to initiate Karnataka Watershed Development Project with a redesigned institutional approach. This approach is unique in three respects viz., (i) Building up of the institutions and promoting group action in two spheres connecting farm and non-farm activities (ii) Credit as the most crucial component of the farm economy with the farm development initiatives and (iii) Establishment of village level institutions to ensure participation both in physical and financial programmes as well as sustainability. These unique institutional approaches surely resulted in a good number of income and employment generating activities.

Karnataka has huge responsibility of meeting the challenges of food security through sustained agriculture growth. Karnataka implemented a World Bank funded Sujala 
Watershed development project under participatory mode in as many as 742 micro watersheds coming under 77 sub watersheds in 38 taluks of six districts namely Tumkur, Kolar, Chikkaballapur, Chitradurga, Haveri and Dharwad. The project implemented from September 2001 to March 2010. The project covered 5.19 lakh hectares of geographical area, benefited over 4.19 lakh households inhabiting 1270 villages in three phases. The first phase had a modest target of 10 Sub watersheds, while second covered another 20 Sub watersheds. Major part of the project was implemented in phase III covering as many as 47 Sub watersheds (over 67\% of the all targeted Sub watersheds and as many as 469 Micro watersheds (out of 742).The project covered about 3.32 lakh hectares of area under all the three phases with an average of 82 percent private and 18 percent common land.

The main objectives of the project are,

To reduce the poverty and to improve livelihoods of the people living in the watershed area.

To increase production and productivity of agricultural land 3. To improve the status of natural resource base

To increase the productivity of non-arable lands

To increase capabilities of local institutions for sustainable management of natural resources

To improve skills and create alternate livelihood options for vulnerable families in the watersheds

Keeping in view of the above points, the present study is undertaken with an objective of documenting consequence of Sujala Watershed Project on livelihood of beneficiary farmers and non-beneficiary farmers with respect to source, accessibility, sufficiency, distance, mode of transportation for accessing drinking water, fuel wood, fodder and Income Generation Activities (IGAs).

\section{Materials and Methods}

In Karnataka, there is a separate watershed development department since 1983. Sujala, a world bank assisted watershed project operating in six districts viz., Tumkur, Kolar, Chikkaballapur, Chitradurga, Haveri and Dharwad. This project was started in 2001 with World Bank funds to improve land through watershed development activities by involving local people. Sujala Watershed Project was implemented in three phases in the state. First phase watersheds implemented in 2 taluks of Tumkur district namely Sira and Tiptur. Keeping in view of time and resource limitations, Sira and Tiptur taluks were selected purposefully for the study. Further two sub-watersheds each one from Sira and Tiptur taluk were selected. From each sub watershed, three micro watersheds were selected representing one each in ridge, middle and lower reaches, thus 6 micro watersheds formed the sample for the study. From each selected micro-watershed, 30 beneficiary farmers were selected randomly, which comprises 180 beneficiary farmers from 6 selected micro watersheds. A total of 180 farmers were selected for the study (Table 1).

\section{Results and Discussion}

\section{Consequence of Sujala Watershed Project} on Accessibility to livelihoods

The data presented in Table 2 revealed that a great majority of beneficiary $(68.33 \%)$ and non beneficiary farmers $(73.33 \%)$ dependent on public source for water, whereas a little less than one third $(31.67 \%)$ of beneficiary farmers dependent on their own water source 
compared to 26.67 per cent of non-beneficiary farmers. In case of accessibility to drinking water a majority of beneficiary famers $(78.33$ $\%)$ and non- beneficiary farmers $(76.67 \%)$ were accessible to drinking water. A little less than one forth $(21.67 \%)$ of beneficiary farmers and non- beneficiary farmers (23.33 $\%$ ) were not accessible to drinking water. In case of sufficiency of water, a little less than cent per cent $(93.33 \%)$ beneficiary farmers and 70 per cent of non- beneficiary farmers expressed sufficiency of water while 6.67 per cent of beneficiary farmers and 30.00 per cent of non- beneficiary farmers were felt insufficient availability of drinking water. In case of distance of getting drinking water, greater number of both beneficiary farmers and non- beneficiary farmers (83.33 and 76.67 $\%$ ) were accessing within one kilometre distance, while 14.44 per cent of beneficiary farmers and little less than one forth $(23.33 \%)$ of non- beneficiary farmers were accessing from 1-2 km distance. A few respondents among beneficiary farmers accessed water beyond a distance of $2 \mathrm{~km}$. The mode of transportation to fetch water through manual transportation was more among beneficiary farmers $(79.44 \%)$ as well as non- beneficiary farmers $(90.00 \%)$ and 20.56 per cent of beneficiary farmers and 10 per cent of nonbeneficiary farmers carried the drinking water through vehicle transportation.
The data presented in Table 2 shows that, the fuel wood for 68.89 per cent of beneficiary farmers and 70 per cent of non- beneficiary farmers was from public source, whereas a little less than one third $(31.11 \%)$ of beneficiary farmers and of non- beneficiary farmers $(30.00 \%)$ had access to their own source. Regarding accessibility to fuel wood, majority of beneficiary farmers $(78.33 \%)$ and non-beneficiary farmers $(63.33 \%)$ were accessible. Little less than one forth $(21.67 \%)$ of beneficiary farmers and little more than one third $(36.67 \%)$ of non-beneficiary farmers were not accessible to fuel wood.

With regard to sufficiency of fuel wood, majority of beneficiary $(71.67 \%)$ and nonbeneficiary $(66.67 \%)$ farmers felt sufficient while 28.33 per cent per cent of beneficiary farmers and one third of non- beneficiary farmers thought insufficient. With regard to distance of getting fuel wood, nearly fifty per cent $(48.33 \%)$ of beneficiary farmers and 43.33 per cent of non- beneficiary farmers obtained within one kilometre distance, while little more than one third $(35.00 \%)$ of beneficiary farmers and 26.67 per cent of nonbeneficiary farmers get fuel wood within 2.00 $\mathrm{km}$ distance. 16.67 per cent of beneficiary farmers and 30.00 per cent of non-beneficiary farmers obtained fuel wood from more than $2.00 \mathrm{~km}$ distance.

Table.1 Taluk-wise Sub-watersheds selected for the study

\begin{tabular}{|c|c|c|c|c|}
\hline Taluk & Sub-watershed & Micro watershed & $\begin{array}{l}\text { Beneficiary } \\
\text { farmers }\end{array}$ & $\begin{array}{c}\text { Non- } \\
\text { Beneficiary } \\
\text { farmers }\end{array}$ \\
\hline \multirow{3}{*}{ Sira } & \multirow{3}{*}{ Devarathorehalla } & Echalahalla (R) & 30 & \multirow{3}{*}{15} \\
\hline & & Donnehalla (M) & 30 & \\
\hline & & Maruthi (V) & 30 & \\
\hline \multirow{4}{*}{ Tiptur } & \multirow{3}{*}{ Bidarekattehalla } & Kalpatharu (R) & 30 & \multirow{3}{*}{15} \\
\hline & & Ganga (M) & 30 & \\
\hline & & Doddasethuve (V) & 30 & \\
\hline & & & 180 & 30 \\
\hline \multicolumn{3}{|c|}{ Total } & \multicolumn{2}{|c|}{210} \\
\hline
\end{tabular}


Table.2 Consequences of Sujala Watershed Project on accessibility to livelihoods

\begin{tabular}{|c|c|c|c|c|c|c|}
\hline \multirow[t]{2}{*}{$\begin{array}{l}\text { Natural } \\
\text { resources }\end{array}$} & \multirow{2}{*}{\multicolumn{2}{|c|}{ Particulars }} & \multicolumn{2}{|c|}{$\begin{array}{c}\text { Beneficiary farmers } \\
\qquad\left(\mathbf{n}_{1}=180\right)\end{array}$} & \multicolumn{2}{|c|}{$\begin{array}{l}\text { Non-beneficiary } \\
\text { farmers }\left(\mathbf{n}_{2}=30\right)\end{array}$} \\
\hline & & & F & $\%$ & $\mathbf{F}$ & $\%$ \\
\hline \multirow{11}{*}{$\begin{array}{l}\text { Drinking } \\
\text { water }\end{array}$} & \multirow{2}{*}{ Source } & Public & 123 & 68.33 & 22 & 73.33 \\
\hline & & Own & 57 & 31.67 & 8 & 26.67 \\
\hline & \multirow{2}{*}{ Accessibility } & Accessible & 141 & 78.33 & 23 & 76.67 \\
\hline & & Not & 39 & 21.67 & 7 & 23.33 \\
\hline & \multirow[t]{2}{*}{ Sufficiency } & Sufficient & 168 & 93.33 & 21 & 70.00 \\
\hline & & Not & 12 & 06.67 & 9 & 30.00 \\
\hline & \multirow{3}{*}{ Distance } & $0-1.00 \mathrm{~km}$ & 150 & 83.33 & 23 & 76.67 \\
\hline & & $1.1-2.00$ & 26 & 14.44 & 7 & 23.33 \\
\hline & & $>2.00 \mathrm{~km}$ & 4 & 02.22 & 0 & 0.00 \\
\hline & \multirow{4}{*}{$\begin{array}{l}\text { Mode of } \\
\text { transnortation } \\
\text { Source }\end{array}$} & Manual & 143 & 79.44 & 27 & 90.00 \\
\hline & & Vehicle & 37 & 20.56 & 3 & 10.00 \\
\hline \multirow[t]{11}{*}{ Fuel wood } & & Public & 124 & 68.89 & 21 & 70.00 \\
\hline & & Own & 56 & 31.11 & 9 & 30.00 \\
\hline & \multirow{2}{*}{ Accessibility } & Accessible & 141 & 78.33 & 19 & 63.33 \\
\hline & & Not & 39 & 21.67 & 11 & 36.67 \\
\hline & \multirow{2}{*}{ Sufficiency } & Sufficient & 129 & 71.67 & 20 & 66.67 \\
\hline & & Not & 51 & 28.33 & 10 & 33.33 \\
\hline & \multirow{3}{*}{ Distance } & $0-1.00 \mathrm{~km}$ & 87 & 48.33 & 13 & 43.33 \\
\hline & & $2.00 \mathrm{~km}$ & 63 & 35.00 & 8 & 26.67 \\
\hline & & $>2.00 \mathrm{~km}$ & 30 & 16.67 & 9 & 30.00 \\
\hline & \multirow{2}{*}{$\begin{array}{l}\text { Mode of } \\
\text { transportation }\end{array}$} & Manual & 91 & 50.55 & 17 & 56.67 \\
\hline & & Vehicle & 82 & 45.56 & 13 & 43.33 \\
\hline \multirow[t]{11}{*}{ Fodder } & \multirow[t]{2}{*}{ Source } & Public & 114 & 63.33 & 17 & 56.67 \\
\hline & & Own & 56 & 31.11 & 13 & 43.33 \\
\hline & \multirow[t]{2}{*}{ Accessibility } & Accessible & 138 & 76.67 & 19 & 63.33 \\
\hline & & Not & 42 & 23.33 & 11 & 36.67 \\
\hline & \multirow[t]{2}{*}{ Sufficiency } & Sufficient & 129 & 71.67 & 20 & 66.67 \\
\hline & & Not & 49 & 27.22 & 10 & 33.33 \\
\hline & \multirow{3}{*}{ Distance } & $0-1.00 \mathrm{~km}$ & 102 & 56.67 & 10 & 33.33 \\
\hline & & $1.1-$ & 33 & 18.33 & 12 & 40.00 \\
\hline & & $>2.00 \mathrm{~km}$ & 45 & 25.00 & 8 & 26.67 \\
\hline & \multirow{2}{*}{$\begin{array}{l}\text { Mode of } \\
\text { transportation }\end{array}$} & Manual & 98 & 53.33 & 23 & 76.67 \\
\hline & & Vehicle & 61 & 33.89 & 9 & 30.00 \\
\hline
\end{tabular}


Table.3 Consequences of Sujala Watershed Project on income generating activities of beneficiary and non-beneficiary farmers

\begin{tabular}{|c|c|c|c|c|c|}
\hline \multirow[t]{2}{*}{$\begin{array}{l}\text { SI. } \\
\text { No. }\end{array}$} & \multirow[t]{2}{*}{ Item } & \multicolumn{2}{|c|}{$\begin{array}{l}\text { Beneficiary farmers } \\
\qquad\left(\mathbf{n}_{1}=\mathbf{1 8 0}\right)\end{array}$} & \multicolumn{2}{|c|}{$\begin{array}{l}\text { Non-beneficiary farmers } \\
\qquad\left(\mathbf{n}_{2}=30\right)\end{array}$} \\
\hline & & $\mathbf{F}$ & $\%$ & $\mathbf{F}$ & $\%$ \\
\hline 1 & Tailoring & 31 & 17.22 & 4 & 13.33 \\
\hline 2 & Pot making & 11 & 6.11 & 0 & 0.00 \\
\hline 3 & Pappad or pickle making & 9 & 5.00 & 2 & 6.67 \\
\hline 4 & Leaf plates making & 26 & 14.44 & 2 & 6.67 \\
\hline 5 & Rope making & 43 & 23.89 & 3 & 10.00 \\
\hline 6 & Agarbathi making & 39 & 21.67 & 1 & 3.33 \\
\hline
\end{tabular}

With regard to mode of transportation to collect fuel wood, little more than half (50.55 $\%)$ of beneficiary farmers and non-beneficiary $(56.67 \%)$ farmers used manual transportation, whereas 45.56 per cent beneficiaries and 43.33 per cent non-beneficiary farmers collected through vehicular transportation.

The data presented in Table 2 revealed that, the fodder for 63.33 per cent of beneficiary farmers and 56.67 per cent of non-beneficiary farmers was from public source while, 31.11 per cent of beneficiary farmers and 43.33 per cent of non-beneficiary farmers dependent on their own source, which implies a positive impact of Sujala project programme.

In case of accessibility to fodder, a greater number of beneficiary as well as nonbeneficiary farmers were accessible to fodder (76.67and $63.33 \%$ respectively) contrast to this 23.33 per cent of beneficiary farmers and 36.67 per cent of non-beneficiary farmers were not accessible.

With respect to sufficiency of fodder, 71.67 per cent of beneficiary farmers and 66.67 per cent of non-beneficiary farmers were felt sufficient while, for 27.22 per cent of beneficiaries and 33.33 per cent of nonbeneficiary farmers, fodder was insufficient.
In case of distance of getting fodder, 56.67 per cent of beneficiaries and 33.33 per cent of non- beneficiaries obtained within one kilometre while 18.33 per cent of beneficiaries and 40 per cent of the non-beneficiaries obtained from a distance of $1-2 \mathrm{~km}$ and remaining 25 per cent of beneficiaries and 26.67 per cent of non- beneficiaries procured fodder from more than $2.00 \mathrm{~km}$ distance.

With regard to mode of transportation of fodder, little more than half $(53.33 \%)$ of beneficiary farmers and little more than three forth $(76.67 \%)$ of non-beneficiaries transported through manual transportation whereas one third $(33.89 \%)$ beneficiaries and 30.00 per cent non-beneficiaries transported through vehicle. In case of distance of getting drinking water, fuel wood and fodder, it is decreased in case of beneficiary farmers after implementation of project. The manual mode of transportation for fetching water is decreased and vehicle transportation was increased after implementation of Sujala project.

\section{Consequences of Sujala Watershed Project on Income Generating Activities (IGAs)}

The data in Table 3 shows that 23.89, 21.67 and 17.22 per cent of beneficiary farmers were involved in IGA's like rope making, agarbathi 
making and tailoring respectively. Whereas, among non beneficiary farmers 13.33 per cent are involved in tailoring and equal (6.67\%) per cent of non beneficiary farmers involved in pappad or pickle making and leaf plate making.

The above findings might be due to promotion of income generating activities by Sujala Watershed Project. The main objective of Income Generating Activities is to improve the socio-economic condition of the vulnerable families by supporting them to become successful entrepreneurs.

Under Sujala, SHGs are formed and SHGs have established linkage with financial institutions for their sustainability. The results of Radhakrishna (2005) have the support of the present findings.

The overall improved accessibility to livelihoods is due to the projects' water conservation structures, afforestation programs of common lands which in turn help the underground water recharge, canopy coverage and also helped the farmers to adopt scientific fodder cultivation practices.

As there was little participation in Income Generating Activities there is a need to promote Income Generating Activities especially for women to become self-reliant and to support their families. It needs more coordination among the group members for success, which was a bit difficult to attain by the respondents. Further, it needs family support too.

\section{References}

Ashley, C. and Carney, D., 1999, Sustainable livelihoods: Lessons from early experience, 7: 1. London: Department for International Development.

Carney, D., 1998, Implementing the sustainable rural livelihoods approach. Sustainable rural livelihoods: What contribution can we make, 3:27.

Radhakrishna, S. G., 2005, Capacity building of SHGs of Sujala Watershed in Kolar district- An analysis, M.Sc. (Agri.) Thesis, University of Agricultural sciences, Bangalore.

Sadaqath, S. and Devendrappa, S., 2011, Impact of watershed programme practices of production and productivity of paddy on adoption level of farmers. J. Farm Sci., 1 (1): 132-136.

Shilpa V. C., Suvagiya Daya and Rameshchandra, S., 2017, Watershed development programmes: an evaluation and its impact in India. Intl. Res. J. Social Sci. 6 (2):5-17.

Singh, K., Sandhu, H. S. and Singh, M. N., 1989, Socio-economic impact of Kandi watershed and area development project in Punjab. Indian J. Agric. Eco., 44 (7): 282-283.

Turton, 2000, Community development in sustainable livelihoods approaches-an introduction. Community development journal, 38 (3):185-198.

\section{How to cite this article:}

Mahalakshmi, S. M., V. Govinda Gowda and Thimme Gowda, M. N. 2019. Consequence of Sujala Watershed Project on Accessibility to Rural Livelihood in Tumkur District of Karnataka, India. Int.J.Curr.Microbiol.App.Sci. 8(12): 2099-2105. doi: https://doi.org/10.20546/ijcmas.2019.812.248 